\title{
Muş bölgesindeki üst gastrointestinal sistem malignitelerinin özellikleri
}

\section{Features of the upper gastrointestinal system malignancies in the Muş region}

(D) Rifat PEKSÖZ ${ }^{1}$, (D) Serkan BORAZAN²

Muş Devlet Hastanesi, ${ }^{1}$ Genel Cerrahi Bölümü, ${ }^{2}$ Gastroenteroloji Bölümü, Muş

\begin{abstract}
Giriş ve Amaç: Özofagus ve mide kanserleri tüm dünyada görülen önemli mortalite ve morbidite nedenlerindendir. Özofagogastroduodenoskopi tan için altın standart yöntemdir. Çalışmamızda ülkemizin doğusunda yer alan Muş Bölgesi'nde tespit edilen üst gastrointestinal sistem malignitelerinin demografik özellikleri, başvuru şikayetleri, tümörün lokalizasyonu ve histopatolojik özellikleri gibi bulguların literatür bilgileri eşliğinde tartışlması amaçlanmıștır. Gerec ve Yöntem: Mus Devlet Hastanesi Endoskopi Ünitesinde Ocak 2016 - Ocak 2020 tarihleri arasında üst gastrointestinal sistem endoskopisi yapılan 8131 ve patoloji sonucu malignite olarak raporlanan 72 hasta hasta retrospektif olarak incelendi. Bulgular: Endoskopi ünitemizde özofagogastroduodenoskopi yapılan 8131 hastanın \%53'ünden biyopsi alındl. Yetmiş iki (\%0.88) hastanın histopatoloji sonucu malign olarak tespit edildi. Malignitelerin 25'i özofagusta (\%34.7), 47'si midede (\%65.3) saptand. Hastaların 38'i erkek (\%52.7), 34'ü kadın (\%47,3) olup hastaların yaş ortalaması $64.5 \pm 12.4$ yıldır. Histopatolojik analizlerde özofagus kanseri tanıl hastalarin \%80'i skuamöz hücreli karsinom, \%20'si adenokarsinom idi. Mide tümörlerinin ise \%85.1'i adenokarsinom, \%10.6'sı intramukozal invaziv karsinom ve \%4.3'ü nöroendokrin karsinom idi. Sonuç: Muş Bölgesinde üst gastrointestinal sistem kanserleri görülme sıklı̆̆ Doğu Anadolu Bölgesi’ndeki bazı bölgelerle benzer, bazı bölgelerle farklı özellikler göstermektedir Bu çalışmanın bölge kanser epidomiyolojik çalışmalarına katkı sağlayacağını düșünmekteyiz.
\end{abstract}

Anahtar kelimeler: Özofagus kanseri, mide kanseri, demografik özellikler

\section{GİRIS}

Özofagus ve mide kanserleri tüm dünyada görülen önemli morbidite ve mortalite nedenlerindendir. Özofagogastroduodenoskopi (ÖGD) tanı için altın standart yöntemdir (1). Üst gastrointestinal sistem (GIS) malignitelerinin en sık görülen semptomları; yutma güçlügü, epigastrik bölgede ağrı, retrosternal yanma, dispepsi, kanama, bulantı, kusma ve kilo kaybıdır (2). Üst GIS maligniteleri genelde ileri yaşlarda görülmesine rağmen 30'lu yaşlarda da görülebilmektedir. Özellikle disfaji ve epigastrik ağrı durumunda uyanık olunmalı ama nonspesifik belirti gösterebileceği de akılda tutulmalıdır.

Çalışmamızda ülkemizin doğusunda yer alan Muş Bölgesi'nde tespit edilen üst GIS malignitelerinin demografik özellikleri, başvuru şikayetleri, tümörün lokalizasyonu ve histopatolojik özellikleri gibi bulguların literatür bilgileri eşliğinde tartışılması amaçlanmıştır.
Background and Aims: Esophageal and gastric cancers are the major causes of mortality and morbidity worldwide. Esophagogastroduodenoscopy is the gold standard method for the diagnosis of these cancers. We aimed to discuss the findings including demographic characteristics, symptoms at presentation, localization of the tumor, and histopathological characteristics of the upper gastrointestinal malignancies detected in the Mus area, Eastern Turkey in the light of relevant literature data. Materials and Methods: A total of 8131 patients who underwent upper gastrointestinal endoscopy between January 2016 and January 2020 at the Endoscopy Unit of Mus State Hospital were retrospectively analyzed, and 72 patients whose were diagosed pathologically with a malignancy were examined. Results: Biopsy was performed for 53\% of the 8131 patients who underwent esophagogastroduodenoscopy in our endoscopy unit. Histopathology results of $72(0.88 \%)$ patients were reported to be malignant. Of these cases, 25 had tumor in the esophagus (34.7\%) and 47 had it in the stomach (65.3\%). Of all, 38 (52.7\%) patients were men and $34(47.3 \%)$ were female. The mean age of the patients was $64.5 \pm 12.4$ years. Histopathological analyses revealed that $80 \%$ of the patients with esophageal cancer also had squamous cell carcinoma, while $20 \%$ had adenocarcinoma. Of the stomach tumors, $85.1 \%$ were adenocarcinoma, $10.6 \%$ were intramucosal invasive carcinoma, and $4.3 \%$ were neuroendocrine carcinoma. Conclusion: The incidence of upper gastrointestinal cancers in the Mus area demonstrated similar characteristics with the reports from some areas in the Eastern Anatolia region, but different characteristics with those from some other areas. We therefore believe that the present study will contribute to the existing information obtained by cancer epidomiology studies conducted in these regions.

Key words: Esophageal cancer, gastric cancer, demographic features

\section{GEREC ve YÖNTEM}

Bu çalışma için Erzurum Bölge Eğitim ve Araştırma Hastanesi Etik Kurulu'ndan 2020/06-67 karar numarası ile onay alındiktan sonra, Muş Devlet Hastanesi Endoskopi Ünitesi'nde Ocak 2016 - Ocak 2020 tarihleri arasında ÖGD yapilan 8131 hasta retrospektif olarak incelendi ve patoloji sonucu malignite olarak raporlanan 72 hasta değerlendirmeye alındı. Hastaların cinsiyeti, yaşı, başvuru şikayeti, lezyonun yeri, tümörün histopatolojik tipi kaydedildi. İstatistiksel analizler için SPSS 23 paket programı kullanıldı. İstatistiki veriler ortalama \pm standart sapma, sayı ya da yüzde olarak gösterildi. Işlem öncesi hasta ve yakınlarına işlem ile ilgili bilgi verildikten sonra hasta rıza onam formu imzalatıldı. Işlem öncesi hastaların en az 8 saat oral yoldan beslenmesi kesildi. İşlem esnasında hastalar monitörize edildi ve oksijen desteği altında işlem yapıldı. İşlem öncesi hastalara oral lokal anestezi (\%10 lidokain sprey) uygulandı.
İletişim: Rıfat PEKSÖZ

Muş Devlet Hastanesi, Genel Cerrahi Bölümü Eski Tekel Depoları Yanı, Bitlis Yolu Üzeri, Muş• Tel : 04362120670 Fax: $0.4362121360 \cdot$ E-mail: kemal_peksoz@hotmail.com Geliş Tarihi: 18.06.2020 Kabul Tarihi: 11.08.2020 


\section{BULGULAR}

Endoskopi ünitemizde ÖGD yapılan 8131 hastanın 4300'ünden (\%53) biyopsi alındı. 72 (\%0.88) hastanın histopatoloji sonucu malign olarak tespit edildi. Hastaların 38'i erkek (\%52.7), 34'ü kadın (\%47,3) olup hastaların yaş ortalaması $64.5 \pm 12.4$ (35-96) ylldı. Malign lezyonların 5'i polipoid yapıda, 67'si ülserovejetan yapıdaydı. Malignitelerin 25'i özofagusta (\%34.7), 47'si midede (\%65.3) saptandı. Duodenumda malignite saptanmadi.

Özofagus kanserlerinin 11'i erkek (\%44), 14’ü kadın (\%56) ve hastaların yaş ortalaması 59.64 \pm 12.4 (37-82) yıldı (Şekil 1). Histopatolojik analizlerde özofagus kanseri tanılı hastaların \%80'i skuamöz hücreli karsinom, \%20'si adenokarsinom idi. Özofagus malignitelerinin \%80'i distal özofagusta, \%12'si orta özofagusta, \%8'i proksimal özofagusta saptandı (Şekil 2). Adenokarsinom tanılı hastalarının tümü distal özofagusta saptandı. Hastaların poliklinik başvurusundaki ana şikayetleri; disfaji (\%56), dispepsi/epigastrik ağrı (\%24), genel vücut ağrısı (\%12), kilo kaybı (\%8) olup \%85 hastada üst gastrointestinal sistem alarm bulguları mevcuttu.

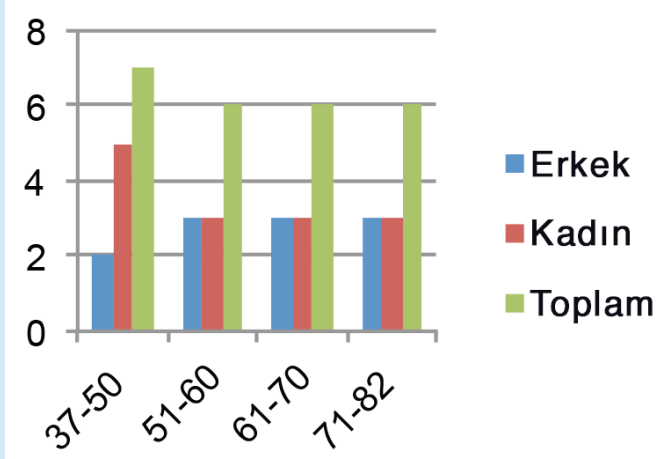

Şekil 1. Özofagus kanseri olgularının yaş dağılımı

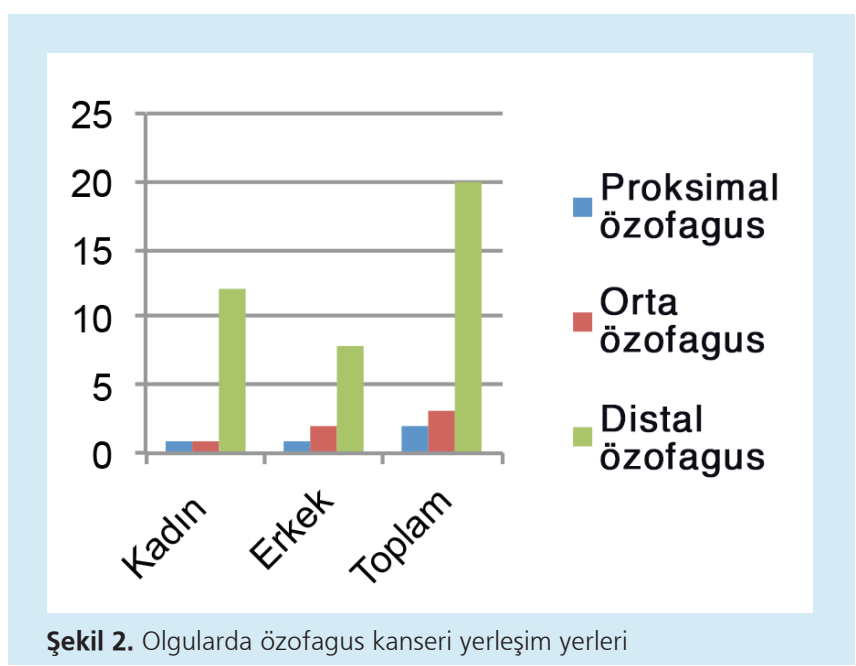

Mide kanseri tespit edilen hastalarm 27'si erkek (\%57.4), 20 'si kadın (\%42.6) idi. Hastaların yaş ortalaması 67.2 \pm 11.7 (35-96) yıldı (Şekil 3). Mide lezyonlarının 20'si korpusta (\%42.5), 17'si antrumda (36.2), 10'u kardiyada (\% 21.2) tespit edildi (Şekil 4). Mide tümörlerinin 40'ı adenokarsinom (\%85.1), 5'i intramukozal invaziv karsinom (\%10.6) ve 2'si nöroendokrin karsinom (\%4.3) idi. Malignite tespit edilen hastaların ÖGD yapılma nedenleri epigastrik ağrı (\%40.4), dispeptik semptomlar (\%14.9), ultrasonografi (USG) ve bilgisayarlı tomografide (BT) tespit edilen midede duvar kalınlık artışı (\%14.9), demir eksikliği anemisi (\%10.6), GIS kanaması (\%6.4), kilo kaybı (\%4.2), bulantı, kusma (\%4.2) ve disfaji (\%4.2) olup \%88 hastada üst gastrointestinal sistem alarm bulguları mevcuttu.

\section{TARTISQMA}

Dünyada en slk görülen sekizinci kanser olan özofagus kanseri, kansere bağlı ölümler sıralamasında 6 . sırada gelmektedir (3). Özofagus kanserleri gelişmekte olan ülkelerde daha sık görülür ve bu kanserler genellikle ileri evrede (inoperabl dönemde) tespit edilmektedir. Özofagus kanseri erkelerde
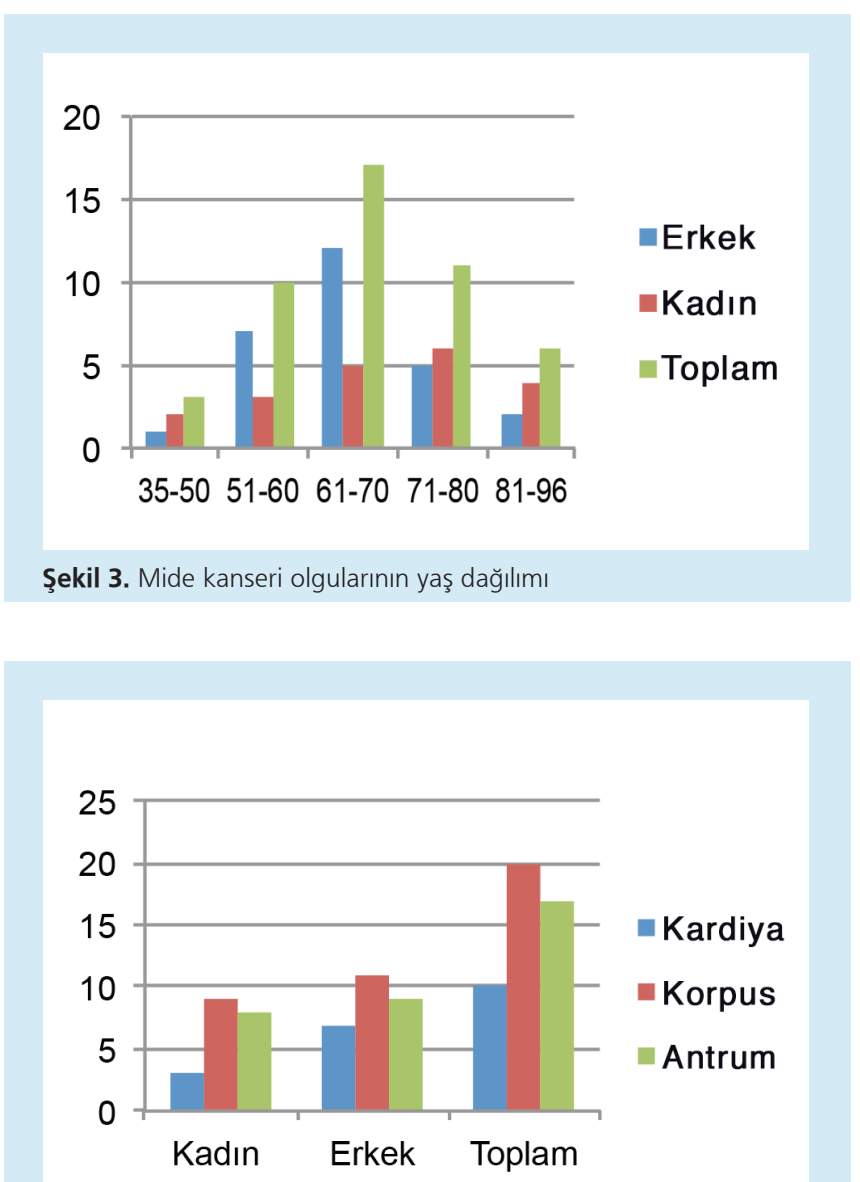

Şekil 4. Olgularda mide kanseri yerleşim yerleri 
daha sık görülmektedir. Türkiye'de 2013 istatistik verilerine göre özofagus kanseri insidansı kadınlarda yüz binde 1.3, erkeklerde ise yüz binde 2.l'dir (4).

Ülkemizde yapılan çalışmalarda demografik özellikler ve özofagus kanseri görülme oranı bölgesel farklllıklar göstermektedir. Doğu Anadolu Bölgesi’nde Van havzasında yapılan çalışmada endoskopi yapılan hastaların \%4.3'ünde özofagus kanseri tespit edilmiştir. Hastaların \%61'i kadın, \%39'u erkek olup, özofagus kanseri kadınlarda erkeklere oranla 1.5 kat daha sık görülmüştür. Ortalama yaş 54.7 saptanmıştır (5). Harran Bölgesi'nde yapılan çalışmada 5286 hastalık seride özofagus kanseri sıklığı \%0.2 oranında ve mide kanseri sıklığı \%0.5 oranında saptanmıştır (6). Elazı̆̆ bölgesinde yapılan 6912 üst GiS endoskopisinin değerlendirildiği bir çalışmada özofagus kanseri \%0.1 olarak raporlanmıștır. Batı Karadeniz Bölgesi'nde yapılan bir çalışmada 7703 olguda özofagus kanseri oranı \%0.06 olarak raporlanmıştır $(2,7)$. Aydın Bölgesi'nde yapılan bir çalışmada endoskopik incelemelerde $\% 2.71$ oranında üst GIS malignitesi tespit edilmiştir. Olguların \%21.l'inde malignite özofagus kaynaklı olup malignitelerin \%61.4'ü erkeklerde, \%38.6'sı kadınlarda saptanmıștır (8).

Çalışmamızda Muş Bölgesi'nde tespit edilen özofagus kanseri hastalarının \%44'ü erkek, \%56'sı kadın ve hastaların yaş ortalaması 59.6 yll olup; endoskopik işlemlerde özofagus kanseri saptanma oranı \%0.3'tür. Türkiye'nin batı bölgelerinde erkeklerde daha sık görülen özofagus maligniteleri çalışmamızda da görüldüğü gibi doğu bölgelerde kadınlarda daha sık görülmektedir.

Disfaji, özofagus kanserinde en sık görülen semptom olup hastaların \%60-70'i lokal ileri ya da metastatik evrede başvurmaktadır (9). Endoskopi polikliniğimize başvuran hastaların büyük çoğunluğunun disfaji (\%56) şikayeti olup, azalan sırasıyla dispeptik şikayetler, yaygın vücut ağrısı, kilo kaybı ve epigastrik ağrı diğer başvuru nedenleridir.

Özofagusun yassı hücreli kanseri genellikle gelişmekte olan ülkelerde görülürken, adenokarsinom ise gelişmiş ülkelerde daha fazla görülmektedir. Skuamöz hücreli karsinom ve adenokarsinom özofagus kanserinin iki ana tümörleridir. Kuzey Iran'dan Merkezi Orta Asya'ya kadar uzanan alanda kanserin en sık rastlandığı ve en yüksek riskli olduğu bölgede, skuamoz hücreli karsinom insidansı \%90 iken, Ingiltere'de bu oran \%26 civarındadır (10). Skuamöz hücreli kanser, servikal-torasik alanda sık görülürken, özofagogastrik bileşkede daha çok adenokarsinom tipi tümörler gözükmektedir (11).

Van bölgesinde Tuncer ve arkadaşlarının yaptığı çalışmada skuamöz hücreli karsinom $\% 80$, adenokarsinom $\% 16$ ve diğer tümörler \%4 oranında görülmüş ve vakaların \%88'inin distal özofagusta görüldüğü bildirilmiștir (5).

Çalışmamızda özofagusta \%80 skuamöz hücreli kanser, \%20 adenokanser saptanmıştır. Tümörlerin \%80'i distal özofagus- ta, \%12'si orta özofagusta, \%8'i proksimal özofagusta yerleşmiştir. Sonuçlar literatürle benzerlik göstermektedir.

Mide kanseri dünyada dördüncü sırada görülen kanser tipi iken, kanser ile ilişkili ölümlerde üçüncü sırada bulunmaktadır (12). Ülkemizde mide kanseri, kadınlarda meme ve kolorektal kanserlerden, erkeklerde akciğer kanserinden sonra en sık görülen kanser tipidir. Genel olarak, erkeklerde kadınlara oranla iki kat daha sık görülür. Ortalama görülme yaşı 60-70 arasındadır $(13,14)$. Ülkemizde mide kanseri görülme oranı \%0.5-4 arasında değişmektedir (7).

Erzurum Bölgesi'nde 504 hastada yapılan çalışmada mide kanseri hastalarının \%36.1'i kadın \%63.9'u erkek olup hastaların yaş ortalaması 62.4 yıldır (15). Elazığ ilinde yapılan çalışmada üst GIS endoskopisinde \%1.3 oranında mide kanseri tespit edilmiştir (7). Van Bölgesi'nde görülen mide kanseri erkeklerde kadınlara göre 1.6 kat daha sık saptanmıştır. Olguların ortalama yaşı 54.8 olup en sık 51-60 (\%39) yaşları arasında görülmüştür. ÖGD yapılan hastalarda mide kanseri görülme oranı \%6.3 olup özofagus kanserine oranla 1.5 kat fazla görülmektedir (5).

Bizim çalışmamızda ÖGD yapılan 8131 hastada mide kanseri görülme oranı \%0.58 idi. Hastaların \%57.4'ü erkek, \%42.6'sı kadın ve yaş ortalamaları 67.2 yıl idi. Mide kanserinin erkeklerde 1.35 kat daha sik görüldügü tespit edildi. Hastaların \%36.1'lik kısmı 6-7. dekatlar arasında idi. Bulgular literatür ile benzerdir.

Mide kanseri sinsi seyreden bir hastalık olduğu için hastalığın geç döneminde bulgu verir. Karakteristik bir semptomu yoktur. Epigastrik bölgede olan belli belirsiz bir rahatsızlık hissi, dolgunluk hissi en sık başlangıç belirtileridir. Bununla beraber inatçı dispepsi, iştahsızlık, disfaji, bulantı, kusma, yorgunluk, halsizlik gibi şikayetler hastaların sağlık merkezine başvurduğu diğer semptomlarıdır (16).

Çalışmamızda mide kanseri görülen hastaların en sık şikayeti epigastrik ağrı (\%40.4) olup, diğer sık ÖGD endikasyonları sırasıyla dispepsi ve radyografik görüntülemede patolojik görüntü izlenmesidir.

Mide kanserlerinin en sık histopatolojik tipi adenokarsinomdur. Türkiye'de yapılan çeşitli çalışmalarda mide kanserlerinin \%93 oranında adenokarsinom, \%2.3 epidermoid kanser, \%2.3 lenfoma, \%1.5 karsinoid tümör ve \%0.9 oranında sınıflandırlamayan malign tümör olduğu tespit edilmiştir. Başka bir çalışmada mide kanserlerinin \%42'si korpusta, \%36's1 antrumda, \%2l'i kardioözofageal bileşkede, \%0.7'si fundusta tespit edilmiş ve \%4'ü diffüz yerleşimli olarak bulunmuştur (5). Erzurum Bölgesi’nde Kısaoğlu ve ark.'nın yaptığı bir çalışmada mide kanserlerinin \%94.5'i adenokarsinom ve tümör yerleşimi \%40.1 antrumda, \%21.2 korpusta, \%38.7 kardiya ve fundusta saptanmıștır (15). 
Çalısmamızda mide kanseri olgularında en sık görülen histopatolojik tip \%85.1 oranında adenokarsinom idi. Lezyonların \%42.5'si korpusta, \%36.2'si antrumda, \%21.2'si kardiyada tespit edildi. Bulgular literatürle paralellik göstermektedir.

Sonuç olarak; Muş Bölgesi'nde üst Gís kanserleri görülme sıklığı Doğu Anadolu Bölgesi'ndeki kimi bölgelerle benzer, kimi bölgelerle farklı özellikler göstermektedir. Mide kanserlerinde erkek oranının kadınlara göre yüksekliği tüm Türkiye'deki

\section{KAYNAKLAR}

1. Parkin DM, Bray F, Ferlay J, Pisani P. Global cancer statistics, 2002. CA Cancer J Clin 2005;55:74-108.

2. Yücel Y, Aktümen A, Aydoğan T, ve ark. Üst gastrointestinal sistem endoskopisi: 7703 olgunun retrospektif analizi. Endosc Gastrointestinal 2016;24:1-3.

3. Siegel RL, Miller KD, Jemal A. Cancer statistics, 2015. CA Cancer J Clin 2015;65:5-29.

4. Gültekin M, Boztaş G, Utku EŞ. Türkiye kanser istatistikleri. Eds I. Şencan, GN Ince T.C. Sağlık Bakanlığı Türkiye Halk Sağlığı Kurumu 2016; 19

5. Tuncer I, Uygan I, Kösem M, et al. Van ve çevresinde görülen üst gastrointestinal sistem kanserlerinin demografik ve histopatolojik özellikleri. Van Tip Derg 2001;8:10-3.

6. Cevheri Ağan Z, Cindoğlu Ç, Ağan V, Uyanıkoğlu A, Yenice N. Harran Üniversitesi Gastroenteroloji Kliniğinde özofagogastroduodenoskopi yapılan olguların demografik verilerinin analizi: 5 yıllık seri. Harran Üniversitesi Tip Dergisi 2019;16:101-4.

7. Polat Y. Endoscopic experience of a surgeon: The evaluation of 8453 cases. Int J Basic Clin Med 2015;3:1-5.

8. Coşkun A, Borazan S, Yükselen V, et al. Features of upper gastrointestinal tract malignancies in Aydin region. Endoscopy Gastrointestinal 2015;23:67-9. çalışmalarla paralellik göstermekle birlikte, özofagus malignitelerinin Doğu'da kadınlarda, Batı'da erkeklerde daha çok görülmesi dikkat çekicidir. Sigara alışkanlığı ve beslenme tipi açısından ileri incelemenin faydalı olacağı düşünülmektedir. Bu çalışmanın üst GIS maligniteleri açısından bölge epidemiyolojik çalışmalarına katkı sağlayacağını düşünmekteyiz.

"Tüm yazarlar herhangi bir çıkar çatışması olmadığını kabul ederler."

9. Baquet CR, Commiskey P, Mack K, Meltzer S, Mishra SI. Esophageal cancer epidemiology in blacks and whites: racial and gender disparities in incidence, mortality, survival rates and histology. J Natl Med Assoc 2005;97:1471-8.

10. Zhang Y. Epidemiology of esophageal cancer. World J Gastroenterol 2013;19:5598-606.

11. Akiyama H, Tsurumaru M, Udagawa H, Kajiyama Y.Radical lymph node dissection for cancer of the thoracic esophagus. Ann Surg 1994;220:36473.

12. Ferlay J, Soerjomataram I, Dikshit R, et al. Cancer incidence and mortality worldwide: sources, methods and major patterns in Globocan 2012. Int J Cancer 2015;136:E359-86.

13. Yalçın B, Zengin N, Aydın F. The clinical and pathological features of patients with gastric cancer in Turkey: A Turkish Oncology Group Study. Turk J Cancer 2006;36:108-15.

14. Göçmen E, Kocaoğlu H. Mide kanseri epidemiyolojisi. T Klin J Surg 2000;5:161-2.

15. Kısaoğlu A, Özoğul B, Yildırgan MI, ve ark. Mide kanserinde cerrahi: 504 Olgu. Abant Med J 2014;3:220-5

16. Nieminen A, Kokkola A, Ylä-Liedenpohja J, et al. Early gastric cancer: clinical characteristics and results of surgery. Dig Surg 2009;26:378-83. 